ISSN: 1679-3013

D.O.I.: 10.5914/to.2011.0060

\title{
CLIMATIC CHANGES, NUTRIENT IMBALANCE AND PRIMARY PRODUCTIVITY IN AQUATIC ECOSYSTEMS
}

\author{
Rita Sofia Santos ANASTÁCIO ${ }^{\mathbf{1}}$ \\ Ulisses Manuel Miranda de AZEITEIRO ${ }^{2}$ \\ Mário Jorge Verde PEREIRA ${ }^{1,3 *}$
}

Recebido em: 06/01/2012

Aceito em: 26/03/2012

\begin{abstract}
Purpose - It's the aim of the authors, based on a minireview of published information, to present a view of possible consequences of climatic changes associated with biogeochemical cycles and nutrients availability to phytoplankton and primary productivity. Approach - In this paper the authors assume the possibility that changes associated with climate will determine the disappearance of many species, a redistribution of that prevailing, and the change of the environmental quality, as well as of the quality and quantity of mass and energy, established and available to consumers. Findings and Social implications - The dependency of the primary productivity on several factors, and their change, the quality and quantity of electromagnetic energy, the proportion of atmospheric gases and dust, the change of temperature patterns, the acidification of water bodies, the introduction and/or remobilization of nutrients and toxic substances associated with biogeochemical cycles and a non-sustainable exploitation of resources, could reduce the flow of energy to higher trophic levels, and may result in problems associated with food security at a local, regional or global scale. Originality The authors highlight the consequences of possible changes on ocean primary productivity due to $\mathrm{pH}$ lowering, due to the increase of carbon dioxide solubilization and associated nutrient imbalance.
\end{abstract}

Keywords: Phytodiversity, phytoplankton, ocean acidification, metals, nutrient imbalances, food chain.

\section{RESUMO}

Propósito - É intuito dos autores, suportado por uma mini revisão de informação publicada, apresentar um cenário de possíveis consequências de alterações climáticas associadas a ciclos biogeoquímicos e à disponibilidade de nutrientes para o fitoplâncton e à inerente produção primária. Abordagem - Neste artigo assumem a possibilidade de que alterações associadas ao clima determinarão o desaparecimento de muitas espécies, uma redistribuição daquelas que prevalecerem, determinarão alterações na qualidade ambiental, assim como a alteração da qualidade e quantidade de massa e energia que estará disponível para os consumidores. Implicações - Alteração de fatores dos quais os produtores primários estão dependentes, a qualidade e quantidade de energia eletromagnética, a proporção de gases e a quantidade de poeiras em suspensão na atmosfera, alterações nos padrões de temperatura, a acidificação da hidrosfera, a introdução e ou remobilização de nutrientes e de substâncias tóxicas associadas aos

\footnotetext{
${ }^{1}$ CESAM e departamento de Biologia, Universidade de Aveiro, 3810-193 Aveiro, Portugal

${ }^{2} \mathrm{CEF}$, Universidade de Coimbra, Coimbra, Portugal and Universidade Aberta, Portugal

${ }^{3}$ AFPR - A For Plankton Research, Aveiro, Portugal
}

Authors is e-mails: a20029@ua.pt, ulisses@uab.pt, mverde@ua.pt

*Corresponding author:

Mário J. Pereira

e-mail adress: mverde@ua.pt

Phone +351234370350 
ANASTÁCiO, R. R. S.; AZEITEIRO, U. M. M. de; PEREIRA, M. J. V. Climatic changes, nutrient imbalance and primary productivity in aquatic ecosystems.

ciclos biogeoquímicos e a exploração não sustentável de recursos, poderá reduzir o fluxo de energia para os níveis tróficos mais elevados, com possível impacto na segurança alimentar das populações à escala local, regional ou global. Originalidade - Os autores salientam as possíveis consequências na diversidade fitoplanctónica e na produtividade primária dos oceanos devido a um eventual abaixamento dos valores de $\mathrm{pH}$ associado à solubilização de dióxido de carbono na hidrosfera e à alteração no equilíbrio e na quantidade de nutrientes disponíveis.

Palavras-chave: fitodiversidade; fitoplâncton; acidificação dos oceanos; metais, balanço de nutrientes; teia alimentar.

\section{Introduction}

Productivity associated with phytoplankton depends on several factors, such as light and associated flow of energy, temperature, $\mathrm{pH}$ and quantity and quality of nutrients.

The diversity of optimum rates and amplitudes tolerated by many species allow the assumption that each organism will occur in a multidimensional vectorial space, away from the origin of axes, the more extreme value or set of parameters that prevail to its existence as a vegetative form. Changes of the equilibrium, which prevail during speciation, will provide the redistribution of phytoplanktonic species in before prohibited latitudes, but will also be responsible for disappearance or non occurrence of many species. The decrease of phytodiversity is largely illustrated in eutrophic environments, or where toxicity, due to several elements, ions or substances, exceeds autochthonous species tolerance. The quantity and quality of light available to primary producers depend not only, of the path till it reaches the aquatic medium surface but also of its hydrodynamism, transparency and depends on the energy associated with the wave length that composes visible light spectrum. Nutrient rich environments frequently present low diversity and high turbidity due to excessive production. The apparent resultant benefit of the high fixation of energy brings problems in the recycling process of matter. This changes the organoleptic characteristics of water which is used in several activities, like cooking and drinking, agriculture and industry. Another problem is that it depletes water from nutrients, facilitating the growth of species with competitive advantages, due to the ability to store these nutrients or mobilize them from other compartments (such as atmospheric nitrogen, fixated by other groups of filamentous cyanobacteria), or to the production of biotoxins against its competitors. Changes of $\mathrm{pH}$ in several aquatic formations, due to carbon dioxide concentration and the increase of global temperature, is enabling the redistribution of species (vide invasive species). This change affects metals speciation and chemical equilibrium of the different chemical species present in aquatic environments (fresh, brackish and marine). Ocean acidification will change concentrations and proportions of dissolved ions, complicating, for example, calcium precipitation, essential for several species and groups of phytoplankton and coral reef formations. The increase of solubility of many metallic species, essential as macro or/and micronutrients, will enable the achievement of toxic concentrations. This will promote a reduction of phytodiversity and the prevalence of less sensitive species.

Inherent to the decrease of plankton diversity is an abundance alteration of several organisms, as well as their capacity to live. Interactions in and between trophic levels will show disturbances. These will be due to the quality and quantity of edible mass and available energy. Blooms of toxic species, such as those belonging to dinoflagellates and cyanobacteria, associated (among others) to higher temperatures will reduce also the space-temporal availability and quality of food. These last factors, frequently referred as lower quality food, will contribute to the change of mass and energy available for higher levels of the trophic chain. These reductions (also associated with extensive fishery) will affect/reach higher levels (human level) and will jeopardize food security in a period in which the debate about alternative energies overcomes the necessity to find an alternative to petroleum and its derivates.

\section{Climatic changes and primary productivity}


ANASTÁCiO, R. R. S.; AZEITEIRO, U. M. M. de; PEREIRA, M. J. V. Climatic changes, nutrient imbalance and primary productivity in aquatic ecosystems.

Phytoplankton contributes to half of the production of organic matter on the planet (FIELD et. al., 1998). This corresponds to $96 \%$ of the annual carbon production by oceanic plankton $\left(23.9 \times 10^{15} \mathrm{gC}\right.$ ) (BUFFLE, 1990). Coastal regions contribute with $25 \%$ of that production (MURRAY, 1994), representing, in average, the double $\left(100 \mathrm{gC} / \mathrm{m}^{2} / \mathrm{yr}\right.$ ) of that estimated for the remaining ocean (RYTHER, 1969). This productivity is limited by the quantity and intensity of light (RYTHER, 1954a) and nutrients (RYTHER, 1954b). Oceanic organic matter can be considered as a derivate of inorganic materials converted into algal biomass via photosynthesis (MURRAY, 1994). This process (carbon fixation and resulting organic flow of energy in aquatic medium) can be presented by the sequence atmosphere/ (light $+\mathrm{CO}_{2}+$ nutrients) - phytoplankton - trophic chain (BUFFLE, 1990), and by the equation $106 \mathrm{CO}_{2}+16 \mathrm{HNO}_{3}+\mathrm{H}_{3} \mathrm{PO}_{4}+122 \mathrm{H}_{2} \mathrm{O} \rightarrow$ (light) $\rightarrow$ $\left(\mathrm{CH}_{2} \mathrm{O}\right)_{106}\left(\mathrm{NH}_{3}\right)_{16}\left(\mathrm{H}_{3} \mathrm{PO}_{4}\right)$ (REDFIELD et. al., 1963).

The Electromagnetic spectrum and the quantity of energy which reaches rivers, lakes and ocean surfaces and that will be available to be used by primary producers depend on the latitude and time of year (KIMBALL, 1928), of its path (PIKE, 1962), of the interaction with atmosphere components, of particle quantity (KIMBALL, 1928; DRUMMOND et. al., 1958), of diverse gases (DRUMMOND et. al., 1958) including water vapor (KIMBALL, 1928; DRUMMOND et al., 1958), carbon dioxide, oxygen, nitrogen, ozone by absorbing and diffusing it (DRUMMOND et. al., 1958).

In the surface (SVERDRUP et. al., 1946; STRICKLAND, 1958) and through the water column (MOREL, 1991, JOHNSEN; SOSIK, 2004) the penetration of light depends on factors like its wavelength energy (the most energetic reaches higher profundities), obstacles (OHLMANN et. al., 1996), pigment concentration (BAKER; SMITH, 1982), organic matter and particles in suspension (MURRAY, 1994).

The concentration of carbon dioxide in atmosphere has been suffering an increment since the beginning of the Industrial Era (MURRAY, 1994), and it has been showing an evolution from 280ppm, existent before that period (and which remained for a large period in earth's history) (IPCC, 2001), to $389 \mathrm{ppm}$ in September 2011 (NOAA, 2011). In 2005, it was of 380 ppm (RAVEN et. al., 2005), which corresponds to an average annual increment, to our period of $1.7 \mathrm{ppm}$. Annual emissions contribute with $7 \times 10^{9} \mathrm{t} \mathrm{C}$, in the form of carbon dioxide, to the atmosphere (SCHLESINGER, 2004) and some projections indicate the possibility of reaching 1000 ppm in 2100 (RAVEN et. al., 2005).

The concentration of carbon dioxide and of species present in ocean waters depend, not only, of the salinity, but also, at a similar salinity, of the $\mathrm{pH}$ of the medium, showing itself, according with that last one and in different percentages, in its molecular form or in the ionic forms of bicarbonate or carbonate $(\mathrm{BUCH}, 1951)$. The modification of the partial pressure of that gas in the atmosphere allows its dissolution in aquatic medium at a greater quantity, till it reaches equilibrium. Its reaction with water allows, by carbonic acid dissociation, the formation of bicarbonate and carbonate. If the buffer capacity of the conjugate acid/base pair exceeds a limit, hydrosphere acidification will take place.

The 'Ocean acidification due to increasing atmospheric carbon dioxide' (RAVEN et. al., 2005) report summarizes the possible effects of the increase of the carbon dioxide in atmosphere, in oceans acidity before and for the XXI century. In the last 200 years has been occurring, due solubilization of carbon dioxide in the ocean, a reduction of 0.1 units in the $\mathrm{pH}$ value (CALDEIRA; WICKETT 2003), corresponding to an increase in the hydrogen ions concentration of $30 \%$ (RAVEN et al., 2005). It is estimated that the increase will reach 0.5 units in the following 90 years. To ensure the average value of 8.2 \pm 0.3 can be reduced to 7.5 - 7.4 (CALDEIRA; WICKETT 2003; RAVEN et. al., 2005), with consequent reduction of hydrogen and carbonate ions in superficial waters. This will affect also metals speciation and its adsorption to organic matter and increment of its free forms (MILLERO et. al., 2009)

\section{The Metals Factor}

In addition to environmental factors such as light, $\mathrm{pH}$, and carbon, is also known the importance that many elements have in algae development. 
ANASTÁCiO, R. R. S.; AZEITEIRO, U. M. M. de; PEREIRA, M. J. V. Climatic changes, nutrient imbalance and primary productivity in aquatic ecosystems.

Many elements are known as essential to a balanced development of phytoplankton, that when scarce can limit its development, or, due to its toxicity, condition phytoplankton development (when in excess). Plants and algae need several elements and substances at different rates of abundance/ availability/ concentration to express entirely their life cycle. Elements and substances contribute to the manifestation of each stage of the cycle in plenitude. These nutrients are (besides phosphorus and nitrogen) vitamins, amino acids and vestigial elements, resultant of biogeochemical processes, but also, and in several cases in great part, of human activity at a local or global scale (domestic, agricultural and industrial); these processes disperse nutrients between and through biosphere compartments.

It is possible to find 90 chemical elements in nature (GREENWOOD; EARNSHAW, 1995), 25 in biological systems (C, O, H, N, P, K, Ca, Mg, S, Fe, Mn, Zn, Cu, Mo, B, Cl, $\mathrm{Na}, \mathrm{V}, \mathrm{Cr}, \mathrm{Si}, \mathrm{Co}, \mathrm{Ni}$, Se, F, I) (SILVA; WILLIAMS, 1991) being, at least, 20 used by plants (SANTOS, 1991).

In what is concerned to vegetal nutrition, elements can be separated in three groups: essential, beneficial (essential elements to some plants, only) and toxic. In the essential group are: $\mathrm{C}, \mathrm{O}, \mathrm{H}, \mathrm{N}, \mathrm{P}, \mathrm{K}, \mathrm{Ca}, \mathrm{Mg}, \mathrm{S}, \mathrm{Fe}, \mathrm{Mn}, \mathrm{Zn}, \mathrm{Cu}, \mathrm{Mo}, \mathrm{B}, \mathrm{Cl}$; in benefitial group are: $\mathrm{Na}, \mathrm{Si}, \mathrm{Co}$ e $\mathrm{Al}$; and in the toxic group can be considered: $\mathrm{Pb}, \mathrm{Cr}, \mathrm{Cd}, \mathrm{Hg}, \mathrm{I}$, $\mathrm{Br}, \mathrm{F}$ e Se (SANTOS, 1991). In algae nutrition requisites also is included these essential elements and some of the beneficial referred, such as $\mathrm{Na}$ to Cyanoprokaryota, and $\mathrm{Si}$ to diatoms (GAUR; RAI, 1994), as well as to Chrysophyceae and some Xanthophyceae, where they appear as component of scales, schist's or of cell wall. These elements, constituents of organic molecules such as proteins and nucleic acids (N) (VINCENT, 1992), enter, like phosphorus, in NADPH and ATP compositions, as well as in less energetic forms, nucleic acids, phospholipids and phosphoproteins. Potassium is involved in sugar and nitrogen metabolisms, and in protein synthesis, in the organic acids neutralization and in enzymes activation. Magnesium is a constituent of chlorophyll and acts as stabilizer particle of ribosomes, maintaining the necessary configuration to protein synthesis. It is indispensable for the maximum functioning of enzymes, intervening in sugar metabolism and it is a cofactor of enzymes which activate phosphorylation process. Sulfur is a component of aminoacids as methionine and cysteine, in vitamins as biotin, thiamine and in ferredoxins. At the micronutrients level it stands out iron $\left(\mathrm{Fe}^{2+}\right.$ e $\left.\mathrm{Fe}^{3+}\right), \mathrm{Mn}^{2+}, \mathrm{Zn}^{2+}$ e $\mathrm{Cu}^{2+}$. Iron is absorbed in the less oxidized forms. It participates in oxi-reduction reactions due to oxidation states +2 and +3 , being part of cytochromes and ferredoxins. Manganese enters in the constitution of enzymes, where it acts through mechanisms of oxi-reduction. It is absorbed in the divalent form. Also zinc is absorbed in the divalent form. It intervenes in enzymes connection to the substrate (SANTOS, 1991). In algae, like it happens to other organisms, some elements ( $\mathrm{Fe}, \mathrm{Zn}, \mathrm{Cu}, \mathrm{Mo}, \mathrm{V}, \mathrm{Cr}, \mathrm{Co}, \mathrm{Ni}, \mathrm{Se}, \mathrm{As}, \mathrm{Sn}$ ) are only necessary in vestigial quantities, participating in enzymatic processes (WILDE; BENEMANN, 1993).

As a result of human activity, many elements have been introduced in biosphere, in a scale that does not permit to biological systems, connected to the biosphere, easy and fast adaptation. The actual exploitation of energetic resources has been changing quantities, proportions and distribution of gases $\left(\mathrm{CO}_{2}, \mathrm{O}_{3}, \mathrm{CH}_{4}\right.$, nitrogen oxides) (SILVA; WILLIAMS, 1991). Also, a great number of metals has been introduced in nature (atmosphere, lithosphere, hydrosphere) by the very diverse human activity. The sources of heavy metals are the natural erosion and the human activity, domestic or industrial. The industrial influence is noticed in the increase of the $\mathrm{Cd}, \mathrm{Cr}, \mathrm{Pb}, \mathrm{Hg}$ and $\mathrm{Zn}$ levels (MEYBECK et. al., 1989; FILIPPIS; PALLAGHY, 1994); also the case of copper levels, present in water, can be due, partially, to non treated domestic effluents, industrial effluents, car exhausts and open incineration (SHIBERT; SHATILA, 1979). These can be associated to car use ( $\mathrm{Ba}, \mathrm{Cd}, \mathrm{Cu}, \mathrm{Ni}, \mathrm{Pb}, \mathrm{Zn})$ and associated to consumption of fossil energy sources, petroleum derivates ( $\mathrm{Cu}, \mathrm{Mn}, \mathrm{Pb}, \mathrm{Sb}, \mathrm{Sr}, \mathrm{Zn}$ ) (LIN et. al., 2005, WANG et. al., 2003) ( $\mathrm{Ag}, \mathrm{Cd}, \mathrm{Ba}, \mathrm{V})$ (LIN et. al., 2005) (Al, $\mathrm{Ca}, \mathrm{Co}, \mathrm{Cr}, \mathrm{Fe}, \mathrm{Mg}, \mathrm{Mo}, \mathrm{Ni}, \mathrm{Si}, \mathrm{Ti}$ ) (WANG et. al., 2003) and coal derivates (As, Se) (MANOLI et. al., 2002; SWIETLICKI et. al., 1996). The development of new technologies, like nanotechnology, can contribute in 
ANASTÁCiO, R. R. S.; AZEITEIRO, U. M. M. de; PEREIRA, M. J. V. Climatic changes, nutrient imbalance and primary productivity in aquatic ecosystems.

the future to the biosphere introduction of those or other elements that are nanoparticles constituents (e.g. Au, Co, Ti (LI et. al., 2007), Zn (YANG; XING, 2009).

Oceanic waters show, in average, $0.120 \mu \mathrm{g} / \mathrm{Kg}$ of $\mathrm{Cu}, 0.390 \mu \mathrm{g} / \mathrm{Kg}$ of $\mathrm{Zn}, 0.480$ $\mu \mathrm{g} / \mathrm{Kg}$ of $\mathrm{Ni}$ and $0.001 \mu \mathrm{g} / \mathrm{Kg}$ of $\mathrm{Pb}$, having, the majority of elements, an atomic number above 21 with concentrations inferior to $1 \mu \mathrm{g} / \mathrm{Kg}$ (QUINBY-HUNT; TUREKIAN, 1983) and occurring in the form of ion pairs or complexes, particularly constituted with carbonate, chloride or hydroxide ions (TURNER et. al., 1981; MURRAY, 1994). These elements can be concentrated by phytoplankton (SORENTINO, 1979; PEREIRA et. al., 2003b). Metals can be rapidly sequestrated by cells or portions of these cells (VOLESKY, 1990). The capacity of biosorption is being dependent of a number of external factors: $\mathrm{pH}$, temperature, bicarbonate and suspended solids (WILDE; BENEMANN, 1993) as of the metal type, ionic form in solution and of the particular type of active site responsible for the metal capture (KUYUCAK; VOLESKY, 1988; VOLESKY, 1990). Other factors can be added to those: light, salinity, cations and anions, sulphur in aminoacids and colloids (FILIPPIS; PALLAGHY, 1994). In metallic complexes bio-absorption by algae, can occur an interaction between functional groups from the surface cellular matrix, allowing substitution processes between metal ligands and algae, or verifying and interaction between ionic metal complexes with polar or charged groups of algae (WATKINS et. al., 1987).

The bio-remove of metals involve active and passive transport processes. Initially a fast and passive process occur, resultant from the metal bond with cellular surface, extracellular matrix, wall and membrane, followed by an active process (WONG; PAK, 1992). Metals capture by cells or its constituents can be made by: adsorption, ionic change (STOKES, 1975), complexation, coordination, chelation and inorganic microprecipitation (VOLESKY, 1990). Each one or the combination of the mechanisms above referred, can contribute to the immobilization of one or several metallic elements. Metallic cations are attracted to sites in cellular surfaces negatively charged (VOLESKY, 1990). From the moment when metal reaches cellular surface, it interacts with the cell wall or membrane (KUYUCAK; VOLESKY, 1990), and it bonds to sites of that surface that show affinity to the metal (WILDE; BENEMANN, 1993). A number of anionic ligands participate in the metal sequestration: phosphate, carboxyl, sulfhydryl and hydroxyl groups from protein membranes (VOLESKY, 1990). This process, normally, is fast and reversible. Bio-absorption is followed, generally, by a slowdown in the process of adsorption. This slowdown can be due to several mechanisms which include: covalent bonds, surface precipitation, oxi-reductions reactions, crystallizations in cell surface and diffusion to cell interior, with sequestration of the metal by cellular proteins and to other intracellular sites (WILDE; BENEMANN, 1993). The two principal mechanisms responsible for bio-absorption, referred by Wilde and Benemann (1993) are ion-exchange, in which ions like sodium, magnesium and calcium, are dislocated by metallic ions, and complexation processes between metals and several functional groups, such as carboxylic acids, amines, thiols, hydroxyl groups, phosphate and carbonyl.

Cell wall composition plays an important role in metals adsorption ( $\mathrm{LORCH}, 1986)$, capture and bonding (KUYUCAK; VOLESKY, 1990), considering the pectins and other substances with capacity to bond with metals present in cell wall; there is a capacity of the cell to store metals (LORCH, 1986), even when the organism is dead (KUYUCAK; VOLESKY, 1988; VOLESKY, 1990; PEREIRA et. al., 2003).

Algae cell walls are constituted by microfibrils, responsible for giving form and rigidity. These microfibrils are embedded in unshaped material of diverse nature. They are constituted by cellulose in Chlorophyta (Volvocales, Chlorococcales, Ulothricales, Desmidiales), Chrysophyceae, Xanthophyceae, Dinophyta, Phaeophyceae and in Rhodophyta. Hemicelluloses can also occur (Chlorophyta - Oedogoniales), showing substances of pectin embedding them (Chrysophyceae, Volvocales, Ulothricales, Zygnematales, Rhodophyta). Some groups show other polymeric chains, constituted by mannans, galactans, sulphated fucose, or by uronic acids like algine (mannuronic and glucuronic acids). Rhodophyta show a diverse polymer carrageenan besides agar and, 
ANASTÁCIO, R. R. S.; AZEITEIRO, U. M. M. de; PEREIRA, M. J. V. Climatic changes, nutrient imbalance and primary productivity in aquatic ecosystems.

sometimes, $\mathrm{CaCO}_{3}$ mixed with cellulose and pectins. Many forms produce polysaccharides which make part of the sheath, as in a Cyanoprokaryota, Xanthophyceae and Volvocales (BOURRELLY, 1968, 1970, 1971, 1972; van den HOEK et al., 1995). Euglenophyta mucilage also shows particular composition (mucopeptides - amine glucose, sulphated glucose, cysteine) (PEREIRA; AZEITEIRO, 2003b). These walls and mucilaginous material can appear impregnated by calcium carbonate (Chrysophyceae, Volvocales), by silica (Bacillariophyceae, Xanthophyceae) and most frequently by iron salts (Chrysophyceae, Desmidiales) conferring rigidity to envelopes (lorica) in Chrysophyceae, in certain Volvocales or, in larger scale, in taxa of Trachelomonas and Strombomonas genera. Few are the constituent monomers of these molecules, whether they are neutral, whether they are oxidated: glucuronic and galacturonic acids. In them we can find frequently forms such as $\mathrm{N}$-acetylglucosamine, constituent of the cyanoprokariota walls (BOURRELLY, 1968, 1970, 1971, 1972). Species from the Trachelomonas genus also possess a very diversified organic matrix (PEREIRA et. al., 2003b) mineralizable (RINO; PEREIRA, 1991a, b). That process is reversible, pH dependent (PEREIRA et. al., 2003b), and the quantity and type of ions, particularly of Fe and/or Mn (RINO; PEREIRA, 1991a, b; PEREIRA et. al., 2003), determining the quantity and quality of energy that crosses the external matrix and reaches photosystems. Some Chrysophyceae have envelopes in a certain way uniquely organic, constituted by cellulose or chitin associated with other polysaccharid or proteins, frequently occurring, in this last case, mineralization due $\mathrm{Fe}$, $\mathrm{Mn}, \mathrm{Ca}$, carbonate and silica compounds (DUNLAP et. al., 1987). The study of species like Kephyrion and Pseudokephyrion (chrysophytes) showed the presence, in their lorica, of iron in the form of manganese spicules and granules, verifying a spatial segregation of these components when both are present (DUNLAP et. al., 1987).

The calcium carbonate, common mineral present in biological systems (SILVA; WILLIAMS, 1991) component of many scales (cocoliths, Coccolithophorids) (van den HOEK et. al., 1995) and loricae of phytoplanktonic species (Phacotaceae) (HEPPERLE; KRIENITZ, 1997), precipitates to calcium concentrations of $5 \times 10^{-3} \mathrm{M}$, and in $1-10 \times 10^{-3}$ $\mathrm{M}$ for $\mathrm{HCO}_{3}{ }^{-}$, being that process sensitive to $\mathrm{pH}$, temperature, pressure, ions and salts concentrations (SILVA; WILLIAMS, 1991). Precipitation of calcium carbonate in Phacotus lenticularis loricas mineralization, also depend on environmental factors, as $\mathrm{pH}$ and saturation of calcium carbonate of the medium (HEPPERLE; KRIENITZ, 1997). Species of Phacotus ( $P$. lenticularis e $P$. sphaericus) use in their loricas construction calcite $\left(\mathrm{CaCO}_{3}\right)$, removing it from the medium. Its occurrence depends on several environmental factors such as temperature $\left(17-22^{\circ} \mathrm{C}\right), \mathrm{pH}(8.30-9.65)$, nutrition (N/P > 7) (KRIENITZ et. al., 1993). Although calcium is the predominant element, other elements can be found, besides sulfur, in Phacotus lenticularis, such as $\mathrm{P}, \mathrm{Cl}, \mathrm{K}, \mathrm{Na}, \mathrm{Al}, \mathrm{Si}$ and, sometimes, As and $\mathrm{Ba}$ (PROCRATSKY, 1982). Other Volvocales, belonging to the Dysmorphococcus genus ( $D$. globosus), have a lorica composed of one part where calcium is a secondary element, occurring iron and manganese as the principal elements (DUNLAP; WALNE, 1993).

Physico-chemical parameters like temperature (WONG et. al., 1978), pH, oxireduction potential, ions composition, mineral particles, organic matter content, light and hydrostatic pressure, influence the chemical form, mobility and availability of elements and substances, and their toxic effects to the biota (BABICH; STOTZKY, 1980).

Individual or combined metals toxicity, in relation with algae, will depend on the type of metal (VERMA et. al., 1993; PEREIRA et al., 2005), $\mathrm{Hg}^{2+}>\mathrm{Ag}^{+}>\mathrm{Cu}^{2+}>\mathrm{Pb}^{2+}>$ $\mathrm{Cd}^{2+}>\mathrm{Zn}^{2+}>\mathrm{Tl}^{-}$(CANTERFORD; CANTERFORD, 1980) of its concentration $\mathrm{Hg}^{2+}>\mathrm{Cu}^{2+}$ $>\mathrm{Cd}^{2+}>\mathrm{Ni}^{2+}>\mathrm{Cr}^{2+}>\mathrm{Zn}^{2+}>\mathrm{Cs}^{2+}>\mathrm{Pb}^{2+}$ (PEREIRA et. al., 2005), and of biotic and abiotic factors (VYMAZAL, 1990). Metals toxicity, combined or not, will depend on the type of its form (metal species), concentration, $\mathrm{pH}$ of the medium and of the presence of natural (phosphate) (VERMA et. al., 1993) or artificial ligands (EDTA, citrate, glycolic acid), being more toxic in its ionic form (STARODUB et. al., 1987) and acid medium (MICHNOWICZ; WEAKS, 1984; STARODUB et. al., 1987; LEE et. al., 1991). As a whole include: the concentration of metal, affinity for binding sites, electronegativity, duration of exposure, concentration of other ions (other heavy metals, phosphorus, calcium, 
ANASTÁCIO, R. R. S.; AZEITEIRO, U. M. M. de; PEREIRA, M. J. V. Climatic changes, nutrient imbalance and primary productivity in aquatic ecosystems.

magnesium), $\mathrm{pH}$, complexing and chelating agents, redox conditions, temperature, light, turbidity and species characteristics (cell wall, mucilage, cell composition), concentration of algological biomass, extracellular products, stage of development, cellular activity (VYMAZAL, 1990) as well as the capacity/ impediment that has to access the site at the cellular level (nucleus, mitochondria, chloroplasts), where it exerts its effect. Extracellular matrices and nature of its composition (VYMAZAL, 1990; PEREIRA et al., 2003) membranes (MIERLE; STOKES, 1976) are important barriers, conditioning the motility of those elements to cell interior (SILVA; WILLIAMS, 1991).

Metals exert larger toxic effects on algae if its concentration increases (PEREIRA et. al., 2005); these effects include reduction in growth rate and death (SORENTINO, 1979; KERRY; LAUDENBACH, 1988; MALLICK; RAI, 1989, 1990; LEE et. al., 1991; WINNER; OWEN, 1991; ASTHANA et. al., 1992; PEREIRA et. al., 2005; RODRIGUEZ, 2011). Metals affect the shape, morphology (SORENTINO, 1979; LAZINSKY; SICKO-GOAD, 1983), the biovolume (THOMAS et. al., 1980; LAZINSKY; SICKO-GOAD, 1983; TORNQVIST; CLAESSON, 1987; GENSEMER, 1990; VISVIKI; RACHLIN, 1992; RODRIGUEZ et. al., 2011), and ultrastructures (GUPTA; ARORA, 1978; SHEHATA; BADR, 1980; HEUMANN, 1987) of algae. They changed ( $\mathrm{Cu}, \mathrm{Cd}, \mathrm{Cr}, \mathrm{Ni}, \mathrm{Zn}$ ) photosynthetic activity (SINGH; SINGH, 1987; RAI; RAIZADA, 1988; GUPTA, 1989; WONG; CHANG, 1991), respiration $(\mathrm{Cu}, \mathrm{Ni})$, carbon dioxide and other nutrients absorption (PETERSON et. al., 1984; MALLICK; RAI, 1990) and its incorporation ( $\mathrm{Ni}, \mathrm{Cu}, \mathrm{Hg}, \mathrm{Cd}$ ) (SASTRY; CHAUDHARY, 1989), pigment content (PETTERSSON et. al., 1985), ATP (STAUBER; FLORENCE, 1987), and DNA (SORENTINO, 1979; SASTRY; CHAUDHARY, 1989). The various groups of algae have different sensitivities to the effects of metals (TAKAMURA et. al., 1989). The planktonic communities are affected by metals such as $\mathrm{Hg}, \mathrm{Cu}, \mathrm{Cd}, \mathrm{Zn}$ and $\mathrm{Pb}$, which causes a decrease in photosynthetic activity (SINGH; SINGH, 1987; RAI et. al., 1991), in productivity, diversity (GACHTER; MÁRES, 1979; FOSTER, 1982; GENTER et. al., 1987; CHAPIN III et. al., 2000) and structure (FOSTER, 1982; WORM; DUFFY, 2003). This changes the community and favors the survival and abundance of less sensitive species (THOMAS; SEIBERT, 1977; GACHTER; MÁRES, 1979; SORENTINO, 1979).

Benthic communities (WILLIAMS; MOUNT, 1965; DICKMAN et. al., 1990) and phytobenthos are also affected (REESE, 1937; DICKMAN et. al., 1990). Immobilization of nutrients such as phosphate by precipitation with aluminum, also changes that diversity. Associated with its toxicity, determines an indirect effect on the abundance of zooplankton (HORNSTROM et. al., 1984).

\section{CONCLUSION}

Productivity associated with phytoplankton (MENDES et. al., 2009; RESENDE et al., 2005, 2007) and other trophic levels (ABRANTES et. al., 2006; AZEITEIRO et. al., 2006; de FIGUEIREDO et. al., 2007, 2009, 2010; MARQUES et. al., 2007; LOPES et. al., 2009) depend on several abiotic factors. The alteration of equilibriums which have been prevailed to its occurrence, (FIGUEIREDO et. al., 2006; PEREIRA; RINO, 2001; PEREIRA; AZEITEIRO, 2003a; PEREIRA et. al., 2010), will able a redistribution of phytoplankton species, but also will preside to the disappearance, or non occurrence, of several species. The decrease of phytodiversity is largely illustrated in eutrophic mediums, or where toxicity due to certain elements, ions and substances exceed tolerance limits of autochthonous species (PEREIRA et. al., 2005; GERHARDT et. al., 2008; RODRIGUEZ, 2011).

The excessive growth of algae (due to a natural or artificial introduction of nutrients in the aquatic environment), leads to deterioration (FIGUEIREDO et. al., 2011; THOMPSON; RHEE, 1994), expressed by higher levels of organic matter, reduction in transparency, color, $\mathrm{pH}$, conductivity / salinity (interior mediums), dissolved oxygen and its percentage saturation, sometimes with its absence in the water (ABRANTES et. al., 2006).

The occurrence of periods of anoxia allows the formation of sulphides and the release, from sediments, of iron, nitrates and phosphorus. The increase of biological 
ANASTÁCIO, R. R. S.; AZEITEIRO, U. M. M. de; PEREIRA, M. J. V. Climatic changes, nutrient imbalance and primary productivity in aquatic ecosystems.

productivity, which characterizes the eutrophication, has negative effects on the remaining biota (THOMPSON; RHEE, 1994) reducing diversity and changing relative abundance (ABRANTES et. al., 2006; FIGUEIREDO et. al., 2006, 2007; LOPES et. al, 2009; MARQUES et. al., 2007). The production of allelopathic substances (FIGUEIREDO et. al., 2004a, 2011), biotoxins (HALLEGRAEFF, 2003; (FIGUEIREDO et. al., 2004b) and of chemical contaminants in the environment has a toxic effect (ABRANTES, 2008) on many different types of organisms and affects the organization of biological processes at a cellular level, population level, communities level and ecosystems level (BOYLE, 1984). Changes in productivity of aquatic ecosystems may also result, admit the authors of this study from the presence of metallic nanostructures, such as those described by Halas (2010). These metallic nanostructures possess the ability to interact with electromagnetic radiation, and may be responsible, if present in abundance in the medium, not due to toxicity of metals by itself (these are inert and/or are not found dissolved) but because they act as chromophores, absorbing and selecting wavelengths that will be available for primary producers.

The reduction in primary productivity over the last century associable to: the climate, temperature of surface waters (BOYCE et. al, 2010), the atmospheric temperature range, the quantity and quality of light, the nutrient levels in which each phytoplanktonic species develops, and pollutants that are able to tolerate, will originate, also, changes in diversity and relative proportions of species of the phytoplankton community, and it can lead to a change in phytogeography, in the quantity and quality of mass, and in energy available (in space and time) for the primary consumers.

Ecosystem services, food, protection provided by coral reefs (DURAIAPPAH et. al., 2005) may be compromised (RAVEN et. al., 2005).

Associated with this phenomenon, the fully exploited or overexploited stocks of fish (FAO, 2009) collected by industrial fishing fleets (WATSON; PAULY, 2001), or the artisan fishing communities that, in the intertidal zone, collect these resources for daily subsistence, can contribute in a significant way to the reduction of energy that may be available to man. The effective management of fisheries resources (MORA et. al., 2009), the catch of ichthyoplankton, of juveniles and non-target species, and the loss of matter and energy transfer to top consumers will certainly carry severe consequences at local, regional or global scale, associated with food security for a world population that continues to grow and has a geographical distribution that is not consistent with the resources generated and/or available.

\section{REFERENCES}

ABRANTES, N.; ANTUNES, S. C.; PEREIRA, M. J.; GONÇALVES, F. Seasonal sucessions of cladoceran and phytoplankton and their interactions in a shallow eutrophic lake (Vela Lake, Portugal). Acta Oecologica, v. 29, p. 54-64, 2006.

ABRANTES, N.; PEREIRA, R.; de FIGUEIREDO, D. R.; MARQUES, C. R.; PEREIRA, M. J.; GONÇALVES, F. A whole sample toxicity assessment to evaluate the sub-lethal toxicity of water and sediment elutriates from a lake exposed to diffuse pollution. Environmental Toxicology. v. 24, n. 3, p. 259-270, 2008.

ASTHANA, R. K.; SINGH, S. P.; SINGH, R. K. Nickel effects on phosphate uptake, alkaline phosphatase, and ATPase of a Cyanobacterium. Bull. Environ. Contam. Toxicol. v. 48, p. 45-54, 1992.

AZEITEIRO, U. M.; BACELAR-NICOLAU, L., RESENDE, P.; GONÇALVES, F.; PEREIRA, M. J. Larval fish distribution in shallow coastal waters off North Western Iberia (NE Atlantic).

Estuarine, Coastal and Shelf Science, v. 69, n. 3-4, p. 554-566, 2006.

BABICH, H.; STOTZKY, G. Environmental factors that influence the toxicity of heavy metal and gaseous pollutants to microorganisms. CRC critical Reviews in

Microbiology, p. 99-145, 1980. 
ANASTÁCIO, R. R. S.; AZEITEIRO, U. M. M. de; PEREIRA, M. J. V. Climatic changes, nutrient imbalance and primary productivity in aquatic ecosystems.

BAKER, K. S.; SMITH, R. C. Bio-optical classification and model in natutal waters, II. Limnol. Oceanogr., v. 27, p. 500-509, 1982.

BOURRELLY, $P$. Les Algues bleues et rouges Les Eugléniens, Peridinians et Cryptomonadines. Tome III, Éditions N. Boubée \& Cie, Place Saint-André-Des-Arts, Paris-VI ${ }^{\mathrm{e}}$, Paris. 1970.

BOURRELLY, P. Les Algues jaunes et brunes Chrysophycées, Phéophycées, Xantophycées et Diatomées. Tome II, Éditions N. Boubée \& Cie, Place Saint-AndréDes-Arts, Paris-VI ${ }^{\mathrm{e}}$, Paris. 1968.

BOURRELLY, P. Les Algues vertes. Tome I, Éditions N. Boubée \& Cie, Place SaintAndré-Des-Arts, Paris-VI ${ }^{\mathrm{e}}$, Paris. 1972.

BOURRELLY, P. Recherches sur les Chrysophycées. Verlag von J. Cramer, Lehre. 1971.

BOYCE, D. G.; LEWIS, M. R.; WORM, B. Global phytoplankton decline over the past century. Nature, v. 466, p. 591-596, 2010.

BOYLE, T. P. The Effect of Environmental Contaminants on Aquatic algae. in SHUBERT, L. E. (Ed.), Algae as Ecological Indicators, Academic Press Inc., London, p. 237-256, 1984.

BUCH, K. Das kohlensaure gleichgewichtsystem im meerwasser. Havsforskn. Inst. Skr., v. 151 , p. 1-18, 1951.

BUFFLE, J. Complexation reactions in aquatic systems: an analytical approach. Ellis Horwood limited, Chichester, Chichester. 1990

CALDEIRA, K.; WICKETT, M. E. Anthropogenic carbon and ocean pH. Nature, v. 425, p. 365-365, 2003.

CANTERFORD, G. S.; CANTERFORD, D. R. Toxicity of heavy metals to the marine diatom Ditylum brightwellii (West) Grunow: Correlation between toxicity and metal speciation. J. mar. biol. Ass. U. K., v. 60, p. 227-242, 1980.

CHAPIN III, F. S.; ZAVALETA, E. S.; EVINER, V. T.; NAYLOR, R. L.; VITOUSEK, P. M.; REYNOLDS, H. L.; HOOPER, D. U.; LAVOREL, S.; SALA, O. E.; HOBBIE, S. H.; MACK, M. C.; DÍAZ, S. Consequences of changing biodiversity. Nature, v. 405, p. 234-242, 2000.

DICKMAN, M. D.; YANG, J. R.; BRINDLE, I. D. Impacts of heavy metals on higher aquatic plant, diatom and benthic invertebrate communities in the Niagara river watershed near Welland, Ontario. Water Poll. Res. J. Canada, v. 25, n. 2, p. 131-159, 1990.

DRUMMOND, A. J.; FRITZ, S.; MOLLER, F.; MORIKOFER, W.; ROBINSON, G. D.; SCUEPP, W. Radiation instruments and measurements. Ann. Intern. Geophys. Yr., v. 5, p. 375. 1958.

DUNLAP, J. R.; WALNE, P. L. Microarchitecture and Mineralization in Loricae of Phacotacean Flagellates. Acta Protozoologica, v. 32, p. 237-243, 1993.

DUNLAP, J. R.; WALNE, P. L.; PREISIG, H. R. Manganese mineralization in chrysophyceae loricas. Phycologia, v. 26, n. 3, p. 394-396, 1987.

DURAIAPPAH, A. K.; NAEEM, S.; AGARDY, T.; ASH, N. J.; COOPER, H. D.; DÍAZ, S.; FAITH, D. P.; MACE, G.; MCNEELY, J. A.; MOONEY, H. A.; OTENG-YEBOAH, A. A.; PEREIRA, H. M.; POLASKY, S.; PRIP, C.; REID, W. V.; SAMPER, C.; SCHEI, P. J. SCHOLES, R.; SCHUTYSER, F.; VAN JAARSVELD, A. Millennium Ecosystem Assessment, 2005 Ecosystems and Human Well-being: Biodiversity Synthesis. World Resources Institute, Washington, DC., Washington, DC. 2005.

FAO. The State of World Fisheries and Aquaculture, FAO Fisheries and Aquaculture Department, Rome. 2008. 
ANASTÁCIO, R. R. S.; AZEITEIRO, U. M. M. de; PEREIRA, M. J. V. Climatic changes, nutrient imbalance and primary productivity in aquatic ecosystems.

FIELD, C. B.; BEHRENFELD, M. J.; RANDERSON, J. T.; FALKOWSKI, P. Primary production of the biosphere: integrating terrestrial and oceanic components. Science, v. 281, p. 237-240, 1998.

FIGUEIREDO, D. R.; ANTUNES, S. C.; PEREIRA, M. J.; GONÇALVES, F. Chronic effects of Aphanizomenon flos-aquae on the survival and reproduction of daphnids. Fresenius Environmental Bulletin, v. 13, n. 7, p. 665-670, 2004a.

Figueiredo, D. R.; AZEITEIRO, U. M.; ESTEVES, S. M.; GONÇALVES, F. J. M.; PEREIRA, M. J. Microcystin producing blooms - a serious global Public Health issue. Ecotoxicology and Environmental Safety, v. 59, n. 2, p. 151-163, 2004b.

FIGUEIREDO, D. R.; GONÇALVES, A. M. M.; CASTRO, B. B.; GONÇALVES, F.; PEREIRA, M. J.; CORREIA, A. Differential inter-and intra-specific responses of Aphanizomenon to nutrient limitation and algal growth inhibition. Journal of Plankton Research, v. 33, n. 10, p. 1606-1616, 2011.

FIGUEIREDO, D. R.; PEREIRA, M. J.; ALEXANDRA, M.; LEONEL, S.; BÁRRIOS, S.; FONSECA, F.; ISABEL H.; CORREIA, A. Bacterial community composition over a dry winter in potentially eutrophic Portuguese water bodies, FEMS Microbiology Ecology, v. 59, p. 638-650, 2007.

FIGUEIREDO, D. R.; PEREIRA, M. J.; CORREIA, A. Seasonal modulation of bacterioplankton community at a temperate eutrophic shallow lake. World Journal of Microbiology and Biotechnology, v. 26, p. 1067-1077, 2010.

FIGUEIREDO, D. R.; REBOLEIRA, A. S. S. P.; ANTUNES, S. C.; ABRANTES, N.; ULISSES, A.; GONÇALVES, F.; PEREIRA, M. J. The effect of environmental parameters and cyanobacterial blooms on phytoplankton dynamics of a Portuguese temperate lake. Hydrobiologia, v. 568, p. 145-157, 2006.

FILIPPIS, L. F.; PALLAGHY, C. K. Heavy Metals: Sources and Biological Effects. In RAI, L. C.; GAUR, J. P. SOEDER, C. J. (Ed.). Advances in Limnology. Algae and Water Pollution. Archiv für Hydrobiologie, v. 42, p. 31-77, 1994.

FOSTER, P. L. Species associations and metal contents of algae from rivers polluted by heavy metals. Freshwater Biology, v. 12, p. 17-39, 1982.

GACHTER, R.; MÁRES, A. MILIMEX, an experimental heavy metal pollution study: Effects of increased heavy metal loads on phytoplankton communities. Schweiz. Z. Hydrol., v. 42, No. 2, p. 228-246, 1979.

GAUR, J. P.; RAI, L. C. Introduction. In RAI, L. C.; GAUR, J. P.; SOEDER, C. J. (Eds.). Advances in Limnology. Algae and Water Pollution. Archiv für Hydrobiologie, v. 42, p. 1-29. 1994.

GENSEMER, R. W. Role of aluminum and growth rate on changes in cell size and silica content of silica-limited populations of Asterionella ralfsii var. americana

(Bacillariophyceae). J. Phycol., v. 26, p. 250-258. 1990.

GENTER, R. B.; CHERRY, D. S.; SMITH, E. P.; CAIRNS, Jr., J. Algal-periphyton population and community changes from zinc stress in stream mesocosms. Hydrobiologia, v. 153, p. 261-275, 1987.

GERHARDT, A.; BISTHOVEN, L. J.; GUHR, K.; SOARES, A. M. V. M.; PEREIRA, M. J. Phytoassessment of acid mine drainage: Lemna gibba bioassay and diatom community structure. Ecotoxicology, v. 17, p. 47-58, 2008.

GREENWOOD, N. N.; EARNSHAW, A. The Chemistry of the Elements. ButterworthHeinemann Ltd., Oxford, Oxford. 1995.

GUPTA, A. B.; ARORA, A. Morphology and physiology of Lyngbia nigra with reference to copper toxicity. Physiol. Plant., v. 44, p. 215-220, 1978. 
ANASTÁCIO, R. R. S.; AZEITEIRO, U. M. M. de; PEREIRA, M. J. V. Climatic changes, nutrient imbalance and primary productivity in aquatic ecosystems.

GUPTA, S. L. Interactive effects of nitrogen and copper on growth of cyanobacterium Microcystis. Bull. Environ. Contam. Toxicol., v. 42, p. 270-275. 1989.

HALAS, N. J. Plasmonics: An Emerging Field Fostered by Nano Letters. Nano Letters, v. 10, p. 3816-3822. 2010.

HALLEGRAEFF, G. M. Harmful algal blooms: a global overview. In HALLEGRAEFF, G. M., ANDERSON, D. M.; CEMBELLA, A. D. (Ed.), Manual on Harmful Marine Microalgae, UNESCO Publishing, Paris, p. 25-49, 2003.

HEPPERLE, D.; KRIENITZ, L. Phacotus lenticularis (Chlamydomonadales, Phacotaceae) zoospores require external supersaturation of calcium carbonate for calcification in culture Phycologia, v. 33, p. 415-424, 1997.

HEUMANN, H. G. Effects of heavy metals on growth and ultrastructure of Chara vulgaris. Protoplasma, v. 136, p. 37-48, 1987.

HOEK, C.; MANN, D. G.; JAHNS, H. M. Algae: An Introduction to Phycology. Cambridge University Press, Cambridge, Cambridge. 1995.

HORNSTROM, E.; EKSTROM, C.; DURAINI, O. Effects of pH and different levels of aluminium on lake plankton in Swedish west coast area. Nyman, L. \& Ericsson, B. (Ed.). Institute of Freshwater Research, Report n. 61. Drottingholm, p. 115-127, 1984.

IPCC. The Third assessment report of the Intergovernmental Panel on Climate Change (IPCC). Cambridge University Press: Cambridge, UK, and New York, NY. 2001. JOHNSEN, S.; SOSIK, H. Shedding Light on Light in the Ocean. Oceanus, v. 43, n. 2, p. 5, 2004.

KERRY, A.; LAUDENBACH, D. E. Influence of iron limitation and nitrogen source on growth and siderophore production by cyanobacteria. J. Phycol., v. 24, p. 566-571, 1988.

KIMBALL, H. H. Amount of solar radiation that reaches the surface of the earth on the land and on the sea, and the methods by which it is measured. Monthly Weather Review, v. 56, n. 10, p. 393-398, 1928.

KRIENITZ, L.; KOSCHEL, R.; GIERING, B.; CASPER, S. J.; HEPPERLE, D. Phenomenology of organismic calcite precipitation by Phacotus in hardwater lakes and ponds of northeastern Germany. Verh. Internat. Verin. Limnol., v. 25, p. 170-174, 1993.

KUYUCAK, N. VOLESKY, B. Biosorbents for recovery of metals from industrial solutions. Biotechnology Letters, v. 10, n. 2, p. 137-142, 1988.

KUYUCAK, N.; VOLESKY, B. Biosorption by Algal Biomass. in VOLESKY, B. (Ed.). Biosorption of heavy metal, CRC Press, Inc., New York, NY, pp. 173-198, 1990.

LAZINSKY, D.; SICKO-GOAD, L. Ultrastrutural modification of three blue-green algae following heavy metal exposure. Micron and Microscopica Acta, v. 14, n. 3, p. 257258, 1983.

LEE, L. H.; LUSTIGMAN, B.; CHU, I. -YU; JOU, H. -L. Effect of aluminum and pH on the growth of Anacystis nidulans. Bull. Environ. Contam. Toxicol., v. 46, p. 720-726, 1991.

LI, J.; TANG, S.; LU. L.; ZENG, H. C. Preparation of nanocomposites of metals, metal oxides, and carbon nanotubes via self-assembly. Journal of American Chemical Society, v. 129, p. 9401-9409, 2007.

LIN, C.-C.; CHEN, S. -J.; HUANG, K. -L. Characteristics of metals in nano/ultrafine/fine/coarse particles collected beside a heavily trafficked road.

Environmental Science \& Technology, v. 39, n. 21, p. 8113-8122, 2005.

LOPES, A. R.; AZEITEIRO, U. M.; BESSA, V. S.; PEREIRA, C.; SALVADOR, S.; ALMEIDA, A.; CUNHA, M. A.; PEREIRA, M. J. Spring pelagic communities of phytoplankton, 
ANASTÁCIO, R. R. S.; AZEITEIRO, U. M. M. de; PEREIRA, M. J. V. Climatic changes, nutrient imbalance and primary productivity in aquatic ecosystems.

cyanobacteria, associated heterotrophic bacteria and viruses in an eutrophic shallow temperate lake. Fresenius Environmental Bulletin, v. 18, n. 5b, p. 875-884, 2009.

LORCH, D. Desmids and heavy metals. I. Uptake of lead by cultures and isolated cell walls of selected species. Nova Hedwigia, v. 56, p. 105-118, 1986.

MALLICK, N.; RAI, L. C. Effects of Heavy Metals on the Biology of a $\mathrm{N}_{2}$-Fixing Cyanobacterium Anabaena doliolum. Toxicity Assessment: An International Journal, v. 5, p. 207-219, 1990.

MALLICK, N.; RAI, L. C. Response of Anabaena doliolum to bimetallic combinations of $\mathrm{Cu}$, $\mathrm{Ni}$ and Fe with special reference to sequencial addition. Journal of Applied Phycology, v. 1 , p. 301-306, 1989.

MANOLI, E., VOUTSA, D.; Samara, C. (2002) Chemical characterization and source identification/apportionment of fine and coarse air particles in Thessaloniki, Greece.

Atmos. Environ., v. 36, p. 949-961.

MARQUES, S. C.; PARDAL, M. A.; PEREIRA, M. J.; GONÇALVES, F.; MARQUES, J. C.; AZEITEIRO, U. M. Zooplankton distribution and dynamics in a temperate shallow estuary. Hydrobiologia, v. 587, p. 213-223, 2007.

MENDES, M. S.; FERNÁNDEZ-GOMEZ, J.; RESENDE, P.; PEREIRA, M. J.; GALINDOVILLARDÓN, P.; AZEITEIRO, U. M. Spatio-temporal structure of diatom assemblages in a temperate estuary. A statico analysis. Estuarine, Coastal and Shelf Science, v. 84, n. 4, p. 637-644, 2009.

MEYBECK, M.; CHAPMAN, D.; HELMER, R. Global fresh water quality: a first assessment. Blackwell Reference. Oxford, Oxford. 1989.

MICHNOWICZ, C. J.; WEAKS, T. E. Effects of pH on toxicity of As, $\mathrm{Cr}, \mathrm{Cu}, \mathrm{Ni}$ and $\mathrm{Zn}$ to Selenastrum capricornutum Printz. Hydrobiologia, v. 118, p. 299-305, 1984.

MIERLE, G.; STOKES, P. M. Heavy metal tolerance and metal accumulation by planktonic algae. Trace Subst. Environ. Health, v. 10, p. 113-122, 1976.

MILLERO, F. J.; WOOSLEY, R.; DITROLIO, B.; WATERS, J. Effect of Ocean Acidification on the Speciation of Metals in Seawater. Oceanography, v. 22, n. 4, p. 72-85, 2009.

MORA, C.; MYERS, R. A.; COLL, M.; LIBRALATO, S.; PITCHER, T. J.; SUMAILA, R.U.; ZELLER, D.; WATSON, R.; GASTON, K.; WORM, B. Management Effectiveness of the World's Marine Fisheries. PLoS Biology, v. 7, n. 6, p. 1-11. 2009.

MOREL, A. Light and marine photosynthesis: a sepctral model with geochemical and climatological implications. Prog. Oceanog., v. 26, p. 263-306, 1991.

MURRAY, J. W. The Oceans. in BUTCHER, S. S.; CHARLSON, R. J.; ORIANS, G. H.; WOLFE, G. V. (Ed.), Global Biogeochemical Cycles, Academic Press Inc., San Diego, SD, pp. 175-211, 1994.

NOAA (2011) http://www.esrl.noaa.gov/gmd/ccgg/trends/ (accessed 19 October 2011).

OHLMANN, J. C.; SIEGEL, D. A.; GAUTIER, C. Ocean Mixed layer Radiant Heating and Solar Penetration: A Global Analysis. Journal of Climate, Vol. 9, p. 2265-2280, 1996.

PEREIRA, C.; AZEITEIRO, U. M.; PEREIRA; M. J. Diatoms and Dinoflagellates of the outer Aveiro estuary, Portugal: Annual variation and Ecology. Fresenius Environmental

Bulletin, v. 19, n. 4a, p. 704-716, 2010.

PEREIRA, M. J.; AZEITEIRO, U. M. Ecological notes on the species of Phacus Dujardin (Euglenophyta) from the central region of Portugal. Acta Oecologica, v. 24, p. S33-S48, 2003a.

PEREIRA, M. J.; AZEITEIRO, U. M. M. Structure, organization and elemental composition of the envelopes of Trachelomonas (Euglenophyta): a review. Acta Oecologica, v. 24, p. S57-S66, 2003b. 
ANASTÁCIO, R. R. S.; AZEITEIRO, U. M. M. de; PEREIRA, M. J. V. Climatic changes, nutrient imbalance and primary productivity in aquatic ecosystems.

PEREIRA, M. J.; AZEITEIRO, U. M. M.; GONÇALVES, F.; SOARES; A. M. V. M. Inorganic composition of the envelopes of Trachelomonas Ehr. (Euglenophyta). Acta Oecologica, v. 24, p. S317-S324. 2003.

PEREIRA, M. J.; RESENDE, P.; AZEITEIRO, U. M.; OLIVEIRA, J.; FIGUEIREDO, D. R. Differences in the Effects of Metals on Growth of two Freshwater Green Algae

(Pseudokirchneriella subcapitata (Korshikov) Hindak and Gonium pectorale Müller).

Bulletin of Environmental Contamination and Toxicology, v. 75, n. 3, p. 515-522, 2005.

PEREIRA, M. J.; RINO, J. A. Ecology of some Euglenophyta taxa. Verh. Internat.

Verein. Limnol. v. 27, p. 3825-3828, 2001.

PETERSON, H. G.; HEALEY, F. P.; WAGEMANN, R. Metal toxicity to algae: A highly pH dependent phenomenon. Can. J. Fish. Aquat. Sci., v. 41, p. 974-979, 1984.

PETTERSSON, A.; HÄLLBOM, L.; BERGMAN, B. Physiological and structural response of the cyanobacterium Anabaena cylindrica to aluminium. Physiol. Plantarum, v. 63, p. 153-158, 1985.

PIKE, A. C. Estimating the Effect of Cloudiness on Incoming Solar Radiation.

Department of Atmospheric Science, Colorado State University, Fort Collins. CER62ACP33, Paper n. 31. p. 1-9, 1962.

PROCRATSKY, L. A. Nutritional, chemical and ultrastructural characterization of the lorica and extracellular mucilage of Phacotus lenticularis (Phacotaceae, Volvocales). Ph.D. Thesis, The University of Tennessee, Knoxville, Knoxville. 1982.

QUINBY-HUNT, M. S.; TUREKIAN, K. K. Distribution of elements in sea water. EOS, v. 64, p. 130-131, 1983.

RAI, L. C.; RAIZADA, M. Impact of Chromium and Lead on Nostoc muscorum: regulation of toxicity by Ascorbic Acid, Glutathione, and sulfur-containing amino acids.

Ecotoxicology and Environmental Safety, v. 15, p. 195-205, 1988.

RAI, L. C.; SINGH, A. K.; MALLICK, N. Studies on photosynthesis, the associated electron transport system and some physiological variables of Chlorella vulgaris under heavy metal stress. J. Plant Physiol., v. 137, p. 419-424, 1991.

RAVEN, J.; CALDEIRA, K.; ELDERFIELD, H.; HOEGH-GULDBERG, O.; LISS, P.; Riebesell, U., SHEPHERD, J.; TURLEY, C.; WATSON, A.; HEAP, R.; BANES, R.; QUINN, R. Ocean acidification due to increasing atmospheric carbon dioxide. Science Policy Section. The Royal Society, London, The Clyvedon Press Ltd, Cardiff, Cardiff. 2005.

REDFIELD, A. C.; KETCHUM, B. H.; RICHARDS, F. A. The influence of organisms on the composition of seawater. in HILL, M. N. (Ed.), The sea, Vol. 2, Wiley-Interscience, New York, NY, pp. 26-77, 1963.

REESE, M. J. The microflora of the non-calcareous streeams Rheidol and Melindwr with special reference to water pollution from lead mines in Cardiganshire. Journal of Ecology, v. 25, p. 383-407, 1937.

RESENDE, P.; AZEITEIRO, U. M.; GONÇALVES, F.; PEREIRA, M. J. Distribution and ecological preferences of diatoms and dinoflagellates in the West Iberian Coastal Zone (North Portugal). Acta Oecologica, v. 32, p. 224-235, 2007.

RESENDE, P.; AZEITEIRO, U.; PEREIRA, M. J. Diatom Ecological Preferences in a Shallow Temperate Estuary (Ria de Aveiro, Western Portugal). Hydrobiologia, v. 544, p. 77-88, 2005.

RINO, J. A.; PEREIRA, M. J. A propósito de Trachelomonas cervicula Stokes (1890) e de Trachelomonas varians Defl. (1924) (Algae, Euglenophyta). Bol. Soc. Brot., v. 64, 20 sér., p. 245-258, 1991a. 
ANASTÁCIO, R. R. S.; AZEITEIRO, U. M. M. de; PEREIRA, M. J. V. Climatic changes, nutrient imbalance and primary productivity in aquatic ecosystems.

RINO, J. A.; PEREIRA, M. J. Estrutura e Composição Química da Lórica de Trachelomonas nigra Swirenko (Algae - Euglenophyta). Rev. Biol. U. Aveiro, v. 4, p. 95-107, 1991b.

RODRIGUEZ, E.; SANTOS, S.; LUCAS, E. PEREIRA, M. J. Evaluation of Chromium (VI) toxicity to Chlorella vulgaris Beijerinck cultures. Fresenius Environmental Bulletin, $v$. 20, n. 2, p. 334-339, 2011.

RYTHER, J. H. Photosynthesis in the Ocean as a Fuction of Light Intensity. Woods Hole Oceanographic Institution, contribution n. 819, p. 61-70, 1954a.

RYTHER, J. H. The ratio of photosynthesis to respiration in marine plankton algae and its effect upon measurement of productivity. Deep-Sea Res., v. 2, p. 134-139, 1954b.

RYTHER, J.H. Photosynthesis and Fish Production in the Sea. Science, v. 166, n. 3901, p. 72-76, 1969.

SANTOS, J. Fertilização, Fundamentos da utilização dos adubos e correctivos. Publ. Europa-América, Mem Martins. Mem Martins. 1991.

SASTRY, P. S.; CHAUDHARY, B. R. Fixation of $\mathrm{CO}_{2}$ and Incorporation of thymidine under heavy metal stress in Closterium moniliferum. Folia Microbiol., v. 34, p. 106-111, 1989.

SCHLESINGER, W. H. Better living through biogeochemistry. Ecology, v. 85, n. 9, p. 2402-2407, 2004.

SHEHATA, S. A.; BADR, S. A. Growth response of Scenedesmus to different concentrations of copper, cadmium, nickel, zinc, and lead. Environ. International, v. 4, p. 431-434, 1980.

SHIBERT, J. G.; SHATILA, T. Certain metals in three coastal algae from Ras Beirut waters. Hydrobiologia, v. 63, n. 2, p. 105-112, 1979.

SILVA, J. J. R.; WILLIAMS, R. J. P. The biological chemistry of the elements: the inorganic chemistry of life. Clarendon Press, Oxford, Oxford. 1991.

SINGH, D. P.; SINGH, S. P. Action of heavy metals on Hill activity and $\mathrm{O}_{2}$ evolution in Anacystis nidulans. Plant Physiol., v. 83, p. 12-14, 1987.

SORENTINO, C. The Effects of Heavy Metals on Phytoplankton. A Review. Phykos, v. 18, n. 1-2, p. 149-161, 1979.

STARODUB, M. E.; WONG, P. T. S.; MAYFIELD, C. I. CHAU, Y. K. Influence of complexation and $\mathrm{pH}$ on individual and combined heavy toxicity to a freshwater green alga. Can. J. Fish. Aquat. Sci., v. 44, p. 1173-1180, 1987.

STAUBER, J. L.; FLORENCE, T. M. Mechanism of toxicity of ionic copper and copper complexes to algae. Marine Biology, v. 94, p. 511-519, 1987.

STOKES, P. Uptake and accumulation of copper and nickel by metal-tolerant strains of Scenedesmus. Verh. Internat. Verein. Limnol., v. 19, p. 2128-2137, 1975.

STRICKLAND, J. D. H. Solar radiation penetrating the ocean. A review of requirements, data and methods of measurement, with particular reference to photosynthetic productivity. J. Fish. Res. Bd. Can., v. 15, p. 453-493, 1958.

SVERDRUP, H. U.; JOHNSON, M. W.; FLEMING, R. H. The oceans. Their physics, chemistry and general biology. ${ }^{\circ}$ Ed., Printice-Hall, New York, NY, 1946.

SWIETLICKI, E.; PURI, S.; HANSSON, H. C.; EDNER, H. Urban air pollution source apportionment using a combination of aerosol and gas monitoring techniques. Atmos. Environ., v. 30, p. 2795-2809 1996.

TAKAMURA, N.; KASAI, F.; WATANABE, M. M. Effects of $\mathrm{Cu}, \mathrm{Cd}$ and $\mathrm{Zn}$ on photosynthesis of freshwater bentic algae. Journal of Applied Phycology, v. 1, p. 39-52, 1989. 
ANASTÁCIO, R. R. S.; AZEITEIRO, U. M. M. de; PEREIRA, M. J. V. Climatic changes, nutrient imbalance and primary productivity in aquatic ecosystems.

THOMAS, W. H.; HOLLIBAUGH, J. T.; SEIBERT, D. L. Effects of heavy metals on the morphology of some marine phytoplankton. Phycologia, v. 19, n. 3, p. 202-209, 1980.

THOMAS, W. H.; SEIBERT, D. L. R. Effects of copper on the dominance and the diversity of algae: controlled ecosystem pollution experiment. Bulletin of Marine Science, v. 27, n. 1, p. 23-33, 1977.

THOMPSON, P. A.; RHEE, G. Y. Phytoplankton Response to Eutrophication. Archiv fur Hydrobiologie, v. 42, p. 125-166, 1994.

TORNQVIST, L.; CLAESSON, A. The influence of aluminium on the cell-size distribution of two green algae. Environmental and Experimental Botany, v. 27, n. 4. p. 481-488, 1987.

TURNER, D.; WILTFIELD, M. DICKSON, A. G. The equilibrium speciation of dissolved components in freshwater and sea water at $25^{\circ} \mathrm{C}$ and $1 \mathrm{~atm}$ pressure. Geochimica et Cosmochimica Acta, v. 45, n. 6, p. 855-881, 1981.

VERMA, S. K.; SINGH, R. K.; SINGH, S. P. Copper toxicity and phosphate utilization in the cyanobacterium Nostoc calcicola. Bull. Environ. Contam. Toxicol., v. 50, p. 192198, 1993.

VINCENT, W. F. The daily pattern of nitrogen uptake by phytoplankton in dynamic mixed layer environments. Hydrobiologia, v. 238, p. 37-52, 1992.

VISVIKI, I.; RACHLIN, J. W. Ultrastructural changes in Dunaliella minuta following acute and chronic exposure to copper and cadmium. Arch. Environ. Contam. Toxicol., v. 23, p. 420-425, 1992.

VOLESKY, B. Biosorption and Biosorbents. in VOLESKY, B. (Ed.), Biosorption of heavy metal., CRC Press, Inc., New York, NY, p. 3-6, 1990.

VYMAZAL, J. Toxicity and accumulation of lead with respect to algae and Cyanobacteria: A Review. Acta hydrochim. hydrobiol., v. 18, p. 513-535, 1990.

WANG, Y. F.; HUANG, K. L.; LI, C. T.; MI, H. H.; LUO, J. H.; TSAI, P. J. Emissions of fuel metals content from a diesel vehicle engine. Atmos. Environ., v. 37, p. 4637-4643, 2003.

WATKINS, J. W.; II, ELDER, R. C.; GREENE, B.; DARNALL, D. W. Determination of gold binding in an algal biomass using EXAFS and XANES spectroscopies. Inorg. Chem., v. 26, p. 1147-1151, 1987.

WATSON, R.; PAULY, D. Systematic distortion in world fisheries catch trends. Nature, v. 424, p. 534-536. 2001.

WILDE, E. W.; BENEMANN, J. R. Bioremoval of heavy metals by the use of microalgae.

Bioth. Adv., v. 11, p. 781-812, 1993.

WILLIAMS, L. G. MOUNT, D. I. nfluence of zinc on periphytic communities. Amer. Jour. Bot., v. 52, n. 1, p. 26-34, 1965.

WINNER, R. W.; OWEN, H. A. Toxicity of copper to Chlamydomonas reinhardtii (Chlorophyceae) and Ceriodaphnia dubia (Crustacea) in relation to changes in water chemistry of a freshwater pond. Aquatic Toxicology, Vol. 21, pp. 157-170, 1991.

WONG, M. H.; PAK, D. C. H. Removal of $\mathrm{Cu}$ and Ni by free and immobilized microalgae.

Biomedical and Environmental Sciences, v. 59, p. 99-108, 1992.

WONG, P. K.; CHANG, L. Effects of copper, chromium and nickel on growth, photosynthesis and chlorophyll a synthesis of Chlorella pyrenoidosa 251. Environ.

Pollution, v. 72, p. 127-139, 1991.

WONG, P. T. S.; CHAU, Y. K.; LUXON, P. L. Toxicity of a mixture of metals on freshwater algae J. Fish. Res. Board Can., v. 35, p. 479-481, 1978. 
ANAStÁcio, R. R. S.; AZEITEIRO, U. M. M. de; PEREIRA, M. J. V. Climatic changes, nutrient imbalance and primary productivity in aquatic ecosystems.

WORM, B.; DUFFY, J. E. Biodiversity, productivity and stability in real food webs TRENDS in Ecology and Evolution, v. 18, n. 12, p. 628-632. 2003.

YANG, K.; XING, B. Sorption of phenanthrene by humic acid-coated nanosized $\mathrm{TiO}_{2}$ and ZnO. Environmental Science \& Technology, v. 43, p. 1845-1851, 2009. 